\title{
Interethnic Conflict: A Challenge for the Future of the Newly Independent States
}

\author{
Andre Kamenshikov
}

\begin{abstract}
This article focuses on the nature of interethnic conflicts in the newly independent states of the former Soviet Union. The author discusses the prevailing patterns that characterize such conflicts and gives a brief account of the changes that took place in the newly independent states over the past decade that laid the ground for the present volatile sociopolitical climate there. Apart from the material causes of conflict, a lot of attention is given to psychological causes such as the loss of identity which is being compensated by a growing nationalism. In the opinion of the author, these psychological causes should be given much more attention in order to predict and prevent outbreaks of interethnic conflicts in the area.
\end{abstract}

\section{Precis}

Cet article etudie la nature des con flits inter-ethniques dans les nouveaux Etats independants de I'Ex-Union Sovietique. L' auteur decrit les principales caracteristiques de ces con flits et donne un bref compte-rendu des changements ayant eu lieu dans ces Etats au cours de la derniere decennie qui sont it I' origine de l' actuel climat sociopolitique volatile dans cette partie du monde. Mis it part les causes materielles de con flit, une attention particuliere es $t$ accordee aux causes psychologiques telle la perte d'identite qui est compensee par une nationalisme grandissant. Selon I' auteur, davantage d' attention doit etre accordee it ces causes

Andre Kamenshikov is Executive Director, Nonviolence International-NIS, 4 Luchnikov Lane, entrance 3, room 2, Moscow, 103982, Russia.

The author expresses his appreciation for editorial comment to Dr. A. Ross Wilcock, Physicians for Global Survival, Canada.

This paper was presented at The Interdisciplinary Conference on the Evolution of World Order: Building a Foundation for Peace in the Third Millennium Toronto, Ontario, June 6-8, 1997. psychologiques afin de predire et prevenir de nouveaux con flits inter-ethniques dans cette region.

Conflicts that developed in the Newly Independent States (NIS) of the former Soviet Union over the past decade surprised an international community unprepared to address the consequences effectively. Even less was it ready to engage in preventive activity. One reason is that these conflicts were unusual in their development, for the whole postsocialist and post-Soviet environment is an essentially new experience. Not all military conflicts in the former Soviet Union can be considered" interethnic". It does not apply, for instance to the October 1993 events in Moscow. One can say that to some extent, most conflicts had an "interethnic" component. The ethnic component may be obvious as in Karabakh, Abkhazia and Ossetia. This paper focuses primarily on conflicts that can be clearly characterized as "interethnic" though some conclusions may apply to other cases.

Seeking to understand interethnic conflicts that developed in the post-Soviet space one may discern strange patterns at first defying understanding:

1) Conflicts are often seen as a dispute over some kind of "pie" -territory, various types of resources, etc. However, in the case of the NIS it is difficult to discern which particular "pie" the dispute was about. While a certain redistribution of resources does occur, along with a serious decrease of everything, it is hard to speculate that this distribution was the real cause of conflict. We may also notice a tendency to see more "struggle over resources" component in conflicts appearing less "interethnic"-such as Chechnya or Tadjikistan.

2) It is difficultto fit the conflicts of the Newly Independent States into an "oppressor-oppressed" framework. Seventy years of Soviet rule had a profound "levelling" effect on the economic development of the regions of the former USSR with the result that it was generally the betterdeveloped regions that perceived themselves to be suffering from the system. But after the disintegration of the USSR these concerns seem to have no reason to linger. When we look at local conflicts it is usually surprising how little evidence of real "oppression" can be found. Commonly, the oppression perceptions of both conflicting parties were much the same on both sides.

3) Finally,butmostastonishing,forthe short-term outcome of interethnic conflicts in the former USSR, we can observe more or less clearly a rule that "the weaker side wins."So far the time frame is insufficient to adequately appreciate long-term consequences. The Ingush-Ossetian conflict in the Suburban region of North Ossetia during 1992 may be an exception where the Ingush population was forced to leave while Ossetian forces were supported in a few days of conflict by Russian Federal troops. In Moldova, Georgia, Azerbaijan and Russia, small ethnic autonomies took on their central governments by an armed struggle reaching de facto independence with control over their own territory. This is commonly explained by claims of foreign interference. My experience throughout five years work as a peace activist in the conflict zones is that while such interference played its role, it was never sufficient to explain the paradox. In the case of the Russian government whose various branches are in constant struggle with each other, in practically every interethnic conflict of former USSR states, Russia sup- 
ported both sides in one way or another and was consequently blamed or held responsible by both sides of each respective conflict.

To understand ethnic conflicts in the )Ost-Soviet states we must first under;tand the character of the changes takng place in these countries over the past iecade. This means renouncing idealisic illusions about the events.

The dramatic change that took place $m$ the territory of the former USSR durng the 1980 s and early 1990s was a 'revolution from the top." It was no nfluenced by the masses at the base of he social pyramid, nor by idealistic ntellectuals or former "dissidents." It vas the huge bureaucratic elite, formed hrough many decades of communist ule, that pushed for reforms. These peo)le had successfully climbed to high evels of the Soviet government apparaus and became tired of the limitations mposed on them by the communist sys:em. Perestroika and glasnost served as heir opportunity to move from manage ial positions to become owners, so they :ould openly use resources under their :ontrol for increased personal coniumption and power. This was a "bour;eois revolution" happening in unique jrcumstances.

Historically, such change came at an arlier stage of industrial development $n$ countries where the majority of the )opulation was peasantry with a fairly )rimitive life style and zero, or a very ow level of, education. Changes in such iocieties would have much greater and nore rapid impact on the position of the lite than on the mass population.

The situation in the USSR was utterly Efferent. The Soviet Union was well ieveloped by many parameters despite ;ome serious deficiencies. More imp or:ant, the old system on the one hand, left Jeople totally unprepared for a market ;ystem, and on the other, had made peoJle extremely dependent on the extenlive social safety net. This comprised :ree (if low quality) medical care, free :and fairly good) education, free :though often $\begin{array}{lrr}\text { inadequate) } & \text { housing, } & \text { mbsidized } \\ \text { transportation, } & \text { utilities, } & \text { tc.- }\end{array}$ transportation, utilities, tc.-
togetherprovided a fairly low but lecent standard ofliving for almost the entire population. People were concerned not that the system was bad in itself, but that it was not functioning properly-it was not sufficiently "just." People were upset not that the system was forcing them to be" equal," but that some were "more equal than others". What first brought popularity to Russia's current president Yeltsin were his statements on the need to cut privileges of the ruling elite. His rhetoric blended well with-as Leo Tolstoy onceputitthat "everybody is satisfied with his brain, but no one is satisfied with his money!"

Taking all into account, itisclearthat the changes that happened went, rightfully or not, directly contrary to the expectations and wishes of most people. This is most notable in the privatization of state property in most post-Soviet states. A very appropriate historical analogy may be the case of European settlers buying for tokens huge pieces of land from American natives who obviously did not appreciate the significance of the transaction.

The changes caused destruction of most pieces of the existing" safety net" which had come to playa vital role in most people's lives. This was all complicated by the wrecking of the Soviet Union as a country and integrated trading region. So while the changes can be characterized as a "revolution from the top" they were like a devastating earthquake, destroying and disrupting the whole political, economic and social fabric of the existing social order. For most people, all that they counted on, hoped for, looked up to, was blown away. In such circumstances, itis amazing how patient and tolerant people have been, and how relatively little turmoil change of such magnitude has created so far.

Along with loss of life's" social fabric," the collective mentality has been severely affected on the psychological level.

Clearly, by no means everyone was totally committed to communist concepts. If this had been the case, such changes would have had no chance of taking place. But at the same time, many elements of communist ideology had become widely accepted and incorporated into the culture. Even before communism, there were collective traditions. Many "dissidents" opposingthe old system wanted to reform it, so it would work according to its officially stated principles and teachings that were conspicuously betrayed by the official custodians. This can be clearly seen by studying the jokes of the times:

"Communist leader Leonid Breznev invites his mother to visit him in Moscow. He shows her his huge apartment, takes her out to a huge mansion, a 'dacha,' and shows her his pool, etc. After he demonstrates all his wealth, she looks at him saying: 'Dear son, I am so happy for you, but I am so afraid of what might happen to you if the Bolsheviks come back!"'

In reality, the main reference frame of "ideological identification" for most people were elements of communist ideology-"Soviet" patriotism (i.e. nationalism) and ethnic, religious and cultural background. The basis for the first two elements was blown away by the gales of change. The more significant these were in people's minds, the more pronounced their perception of loss was.

Loss of social and psychological security led to a terrifying existential vacuum. Along with sudden loss of the Soviet organization and economy came new hardships associated with loss of the familiar "socialfabric." People suddenly exposed to losses and new fears began to take refuge in fundamental ethnic and religious identities. The explosion of "nationalism" was not due to "lifting the lid" from any formerly repressed tensions. It is the direct result and manifestation of profound change.

The need for identity formation, the need to understand one's place and role in life, the need to knowwhatto rely on, whom to trust and how to plan for tomorrow, i.e. psychological orientation and human security, is no less important for survival than the need for food.

Discord in people's minds can become manifest as social unrest or worse. It will be impossible to heal social conflicts without taking care of people's minds and their psychological needs.

Refuge, Vol. 17, No.2 (April 1998) 
Clearly, claims of various ethnic groups sharing the same territory, resources, and a contradictory interpretation of history, set the conditions for conflict. The peculiarity is that there might not be any "objective" reason to explain this. Interethnic conflicts come not as a result of contradictions over specific issues-though such issues are always present in conflicts-they develop on the base of the profound psychologica impact that the changes over the past ten years had on the people of the former USSR. This psychological environment is liable to exploitation by a certain type of political aspirant that preys on national sentiments, historical events, and identifies scapegoats to blame for hardships that people face.

In order to better understand conflict dynamics, in addition to "material" factors (shortage of certain resources, economic inequality, etc.) we must recognize psychological and spiritual factors. It is especially important to understand the perception ofloss over the past years influencing self-identification.

For the ethnic majorities in former Soviet Republics, "psychological loss" may be mitigated by winning independence. Ethnicity for them was relatively stronger than their "soviet" or "socialist" identity. Ethnic minorities in former republics traditionally placed hope in central government to "counterbalance" republican leadership. Now the "counterbalance" is gone, leaving minorities increasingly vulnerable. "Psychologicalloss" may not reflect a visible reality or decline in standards ofliving, availability of resources, etc. Some groups have come to fear losing thei identity in the new environment. Such fear can mobilize strong responses in small or threatened groups and may induce formation of new coalitions or apparently irrational behaviour.

Wars in the former Soviet Union usually show asimilar level of weaponry from the arsenal of the Soviet Army. In the absence of one side having a great technological advantage over the other, the situation favours "resources against dedication". The militaries of the Newly Independent States are sig-

Refuge, Vol. 17, No. 2 (April 1998) nificantly stronger than opponents in terms of resources available, at least at the early stages of conflict. However, opponents are much stronger in the term of dedication to a cause. Wars may be divided into "those which can be lost" and "those which cannot be lost." So far, dedication, based on fear of losing the last "safe haven" in this troubled world-ethnic identity-has proven to be much stronger factor for the outcome of the crisis than visible advantage of having various resources necessary to manage the war. This is explains the socalled "weaker-win" phenomenon. More important than how strong you are, is how afraid are you of losing.

When we look at post-conflict situations today, we can observe that "winners" are in a comparatively worse situation than losers. The absence of economic resources worsened by the lack of international recognition plays its role in the long run. However, this situation only strengthens the power of the ruling elite and allows it to sustain fear of another war among local population, which increases risk for further conflict. Post-war regions suffer from high levels of crime--even compared to the high overall crime level of the former USSR. This facilitates further authoritarian rule (rather characteristic among the NIS states).

Toynbee: One cause for the recent outbreak of lawlessness in a number of fields of life is the turning of men into soldiers in the two world wars, and in the many local wars that have been waged since 1914. War is a deliberate reversal of the normal inhibition against taking human life. For a soldier, killing his fellow human being is a duty instead of being the crime that it is if he commits murder as a civilian. This arbitrary in as a civilian. This arbitrary major ering and demoralizing in itself. Moreover, a soldier on active service is torn out of his customary social setting and is therefore released from all his customary social restraints. When he is commanded to kill, it is no wonder that he also ceases to be governed by other normal inhibitions against raping, looting, and drug taking. The in Vietnam was an extreme case of what always happens to sol-

diers on campaign.

Ikeda: In all ages, war brings this kind of demoralization)

Desperation, crime, and authoritarian rule are factors leading to further strengthening of the existing vicious cycle and, consequently, to the future conflict. On the other hand, as time goes by, people psychologically adjustto the new environment and the possibilities for mobilizing them around the same goals as in the past diminish. This contradictory situation must be well understood when we consider choices the international community may have to address such problems.

It is unjust and counterproductive to try to solve these problems by applying new or other forms of pressure or violence. For example, applying economic sanctions against parties involved serves no one. Helping people to adjust economically and psychologically to the new situation; supporting" grassroots" activities and local NGOs as essential elements needed for building democratic civil societies, is a much better option for conflict prevention and resolution.

If we really want to understand what is going on in NIS states and be able to predict and prevent future outbreaks of violence, we must focus more research on psychological aspects of the present situation. We should examine suchfactors as: what have people lost over the past years in terms of their self-identification; how strong are their fears; and what events or phenomena may trigger violent or explosive responses etc.

My experience with interethnic conflicts is as a peace activist, not a psychologist. However, I have learned from my experience, that we must use psychological insight in analysis of these pre-conflict and conflict situations. A better psychology and wiser therapy seem to be needed in order to cope with continuing challenges in the Newly Independent States.

\section{Notes}

1. Arnold Toynbee and Daisaku Ikeda Choose Life: A Dialogue, edited by Richard L. Gage (London: Oxford University Press, 1976).0 